\title{
Substances, Attributes, and Modes - Substantial Structures in Descartes, Spinoza and Leibniz
}

\author{
HANS BURKHARDT, MUNICH
}

\section{Initial Remarks}

Aristotle introduced the concept of substance in philosophy. Thus, we find reflections on substance in different works of Aristotle. In the Categories, he introduces the so-called ontological square, containing individual substances, universal or second substances, individual accidents and universal accidents. Individual substances are characterized by the fact that they are the final point (end-point) both of inherence and predication, i.e. they are neither contained (in subiecto esse) in another entity nor can they be said or predicated (de subiecto dici) of another entity. ${ }^{1}$ Another well-known characterization of substance, also from Aristotle in the Categories, is the fact that substances are able to receive contrary accidents, i.e. a white substance can become red and vice versa.

Concerning the inherence of an individual accident in an individual substance the Scholastics formulated the so-called non-migration principle: an individual can inhere in only one individual substance, and it cannot migrate from one substance to another. Leibniz formulates this principle in different texts, and he uses it even in his Monadology, where he says in $§ 7$ that accidents can neither be detached from substances, nor wander around outside of substances. And so, neither substances nor accidents can enter a monad from without. ${ }^{2}$

Another fundamental ontological relation is the relation of instantiation that holds between kinds like human being, horse or stone and their corresponding individuals, but also between universal accidents like universal red and individual red, or as Aristotle says, this red. It is worthy of note that Aristotle and the following tradition evidently accepted static acci-

\footnotetext{
${ }^{1}$ See Angelelli 1967, 12.

${ }^{2}$ Cf., Rescher 1991, 17; Burkhardt 1980, 406ff.
} 
dents, too, in contradistinction to many contemporary philosophers who concentrate their analysis exclusively on dynamic accidents or events.

In other works such as Metaphysics and the Physics Aristotle has analyzed substance further and has differentiated between materia prima, materia secunda and substratum (hypokeimenon). All these items are important for philosophers of the seventeenth century, especially the Rationalists.

Another analysis of Aristotle stemming from De Anima is also important for our investigation. Aristotle discriminates in this work between three kinds of souls, i.e. between anima vegetativa, anima sensitiva and anima rationalis. The anima vegetativa or the plant soul is responsible for growing, flourishing, decreasing, reproduction and generally for metabolism, the anima sensitiva or animal soul is responsible for perception, instincts and a certain kind of rudimentary memory, i.e. a purely associative memory, and the anima rationalis or human soul is responsible for thinking or the operating with concepts and a kind of memory far beyond association. This enables us to have contact with the world of ideas. For Aristotle this kind of soul is also possibly independent from the body. The anima vegetativa and the anima sensitiva are able to become non-separable parts of higher souls. Thus the human soul contains both a vegetative and sensitive soul.

A third typical feature of the Aristotelian ontology is natural kinds. Already second substances like human beings, horses or oxen are kinds and are subordinated to kinds of higher order such as animals, bodies and substances. In contrast to philosophers of the twentieth century, for Aristotle these natural kinds are not concepts but entities, which have in his philosophy an important connecting function. They contain necessary relations, and thus, together with the differentiae specificae like corporeal, living and rational they constitute the essential properties of the substances, the properties without which the substance cannot exist. From this it becomes clear that natural kinds are identical with the so called substantial forms, which will play an important role in the philosophy of Leibniz, who tries to manage the rehabilitation of these entities. In the philosophy of Descartes and Spinoza we shall meet the differentiae specificae among the attributes.

In Aristotle there are accidental forms that have also been analysed by the Scholastics. In the philosophy of the Rationalists they do not play an important role. In the philosophy and especially in the metaphysics of the big wheels of seventeenth century rationalist philosophy, Descartes, Spinoza and Leibniz, the concept of substance plays a central role. All 
these philosophers not only use the word substance, but also the concept of substance, and they think also that substances are important and maybe even the most important entities. Each of these philosophers uses another concept of substance, and the decomposition of the substance concept, initiated by Descartes, will be compensated at least in principal by his successors. The historically and systematically interesting aspect consists in the fact that other entities emerge, which should substitute for substances and to which the substance has to be reduced such as the attributes of Descartes and in a certain sense also in Spinoza. The individual concept of Leibniz in the Discours de Métaphysique of 1686, and perception and appetitus in the Monadology of 1714 are also points in case. Following Leibniz, substances are able to build aggregates of different kinds, forming new entities that contain simple substances such as monads or even whole individuals as their parts and constituents. As we have seen, Aristotle and the scholastic philosophers had characterized substances by different items, so for example:

1.1 Substances are the endpoint of both inherence (in subiecto esse, being in a subject) predication (de subiecto dici, said of a subject).

1.2 Substances have essential properties such as being corporeal, living and rational.

1.3 Substances are able to receive contrary accidents or contingent properties.

1.4 Substances persist over time, although they receive contrary accidents.

1.5 The substructure of substances consists of materia prima, materia secunda and substratum.

1.6 True substances are living entities or souls like animals and human beings and not stones.

1.7 There are three different kinds of souls: anima vegetativa, anima sensitiva and anima rationalis. They display a cumulative structure.

\section{Descartes on substance}

Descartes distinguishes in the category of substance between res extensa and res cogitans, i.e. between an extended and a thinking thing. Sometimes he calls them also substances. Each of the two substances is characterized by a special attribute, namely by extension and by thinking. These attributes are the essences or natures of the respective substances, and they are ontologically dominating; that means that the other properties, especially 
perception and imagination in the case of thinking substance and figure and motion in the case of extended substance would be both ontologically and epistemically without any foundation. As a consequence, they could neither be nor be thought of.

If these attributes are the essences of their substances, and consequently are essential properties or predicates, then the learned Aristotelian asks: What is new about this? He knows very well, that the items of the Arbor Porphyriana, namely species and different levels of kinds, belong to the essence of a substance. For example in the case of Peter and Paula, if they are human beings, human being, animal, body and substance belong to them. To these kinds we have to add the differentiae specificae or the differences such as corporeal, living and rational. Now it is easy to see, that the differences are the sources of the Cartesian attributes, because rationalis is identical with thinking and extension comes from corporeal. In the first case the connection is clear, because rationalis and thinking are identical, in the second case we have to consult the negated concept, namely non-corporeal, which characterizes the bodiless minds, understanding that the decisive difference between bodily and bodiless entities consists in extension. ${ }^{3}$ Thus we can see that Descartes in this sense is not a revolutionary but on the contrary a traditionalist. ${ }^{4}$

Besides these two things, entities or substantiata, as Leibniz would call res cogitans and res extensa, there is for Descartes a true substance, namely God. In contradistinction to the two things he is an ens a se, i.e. he is not caused, but he is his own cause, causa sui. For Descartes the rival concept for substance or res is nothing (nihil). Nothing is characterized as having no attributes. ${ }^{5}$ Thus, if one finds an attribute or a mode, then one can be sure, that there exists a substance or a thing, too, consequently a res cogitans or a res extensa. If we apply the metaontological relation of dependence, introduced by Edmund Husserl, to the philosophy of Descartes, we will see that he uses different kinds of dependence: causal dependence, existential dependence and generic dependence.

2.1Causal dependence between God and the created entities, like res extensa and res cogitans.

2.2 Existential dependence between God and these entities.

\footnotetext{
${ }^{3}$ Cf. Petrus Hispanus Portugalensis 1972, 20.

${ }^{4}$ Cf. Gilson 1912, 1967.

${ }^{5}$ Cf. Leibniz: non-Entis nulla esse attributa. Cf. Burkhardt 1980, 103-04.
} 
2.3 Mutual or symmetric existential dependence between res extensa, res cogitans and their essential attributes.

2.4 Existential dependence between the essential attributes and the other important properties. (Perception and imagination on the one hand and figure and motion on the other.)

2.5 Generic dependence between attributes and modes and entities like res cogitans and res extensa.

Short commentaries to $2.1-2.5$ in $2 . \mathrm{I}-2 . \mathrm{V}$

2.I This dependence relation is clear. God has created these entities.

2.II The entities are existentially dependent on God, because on the one hand he is their efficient cause, and on the other he guarantees their existence by his existence and his conservation or creatio continua.

2.III There is an identity between res extensa and extension and res cogitans and thinking, and therefore also a symmetric existential dependence, because there is no res extensa without extension and no res cogitans without thinking.

2.IV Following Descartes, perception and imagination without thinking cannot impossibly exist and are inconceivable, just as are figure (shape) and motion without extension.

2.V Substances are generically dependent on their properties and modes. Concerning modes or accidents Aristotle, the Scholastics, and also Descartes thought that substances are not dependent on certain modes but on modes in general.

Woolhouse knows about Descartes' use of the relation of dependence in his metaphysics as is seen in his book; but it seems that his concept of dependence is primitive or not analysed. ${ }^{6}$ From the book of Anthony Kenny, Woolhouse learned that there are different kinds of dependence. Dependence seems to be a family of relations. Kenny has distinguished between logical and causal dependence. ${ }^{7}$

Another ontological aspect of the concept of substance is the relation of instantiation. Aristotle distinguished first from second substance, and he thought that individual or first substances are instantiations of second or universal substances. Peter and Paula are instantiations of the human spe-

${ }^{6} \mathrm{Cf}$. Woolhouse 1997, 16.

${ }^{7}$ Cf. Kenny 1968, 134. 
cies. Descartes is convinced, too, that human individuals are instantiations of the res cogitans.

Is this also valid for the res extensa? Evidently not, because Descartes knows about the infinite divisibility of material entities and he draws ontological consequences from this fact. Thus, he classifies the res extensa e.g. in gold, lead and ore, and positions it in pieces and other parts. Descartes solves the problem of infinite divisibility mereologically. There is no such a thing like an individual in the realm of res extensa or in the realm of extension, corporeal entities and matter. There are only parts.

What is Descartes' attitude towards existence? For him there are different levels of existence. These levels are: the level of God, the level of substances and attributes, and the level of the modes. The intensity of existence diminishes with the degree of dependence, but on each level there is a kind of existence. ${ }^{8}$

As we have seen, the so-called substantial forms, the content of the Arbor Porphyriana, such as species, kinds and their differences are also part of Descartes' philosophy in a rudimentary form, namely as rationality in the one case and extension in the other. Descartes thought that there is no room for a corporeal substance together with its substantial forms in physics or the science of natural bodies as well as in its application to mechanics or the science of artificial bodies or machines. Already a hundred years before, mechanics had been a mere art, and Descartes was one of the first scientists and philosophers who regarded it as a science.

\section{Spinoza on substance}

Spinoza is looking for another solution to the problem of substance, and he finds it. There is only one substance and it is identical with God. God is an entity that is in itself and not in another entity. Besides this substance there are only attributes and modes. Spinoza defines substance as having an infinite number of attributes, but following Descartes, he knows and distinguishes only two attributes, thinking and extension. Whereas the conceptual difference between substance and attribute in Descartes' case is clear, it is not so in Spinoza's philosophy, because the characterization of God being known by himself also is valid for attributes. Thus, extension, contrary to motion, can be understood by itself, since it is not dependent on another property. The same is valid for thinking which is not dependent on

\footnotetext{
${ }^{8}$ Cf. Woolhouse 1997, 16-17.
} 
perception or imagination. Attributes are the essences of substances, and therefore they are identical with the substance: There are no pure substances or substrata, but only extended substances and thinking substances.

In contrast to Descartes, for Spinoza the res cogitans or thinking substance is not instantiated. If there are neither individuals in the case of res cogitans nor in the case of res extensa, then Spinoza's metaphysics rests on the level of second substances such as human being or stone. God is the exception. He is the only individual substance.

Spinoza, due to his conception of a unique substance avoids the problem of God as the cause of other substances. But he gets new ones. He has to replace the ontological wealth of the Aristotelian-scholastic distinction between universal and individual substances (together with the relation of instantiation between the two entities) by his attributes and modes. Thus, a step in this direction means a diminution of the difference among substances, attributes and modes.

From the fact that the distinction between substance and attribute is weakened in the philosophy of Descartes and that it has no place in the philosophy of Spinoza, in that substances are identified with their characteristic attributes, we can deduce and formulate the following three ontological statements.

3.1 Substance is reduced directly to its leading attributes and indirectly to its concomitant properties.

3.2The natural kinds, in which the Aristotelian individual substances are imbedded, have to be content with a background existence in favour of the attributes.

3.3For Descartes and Spinoza, change in the category of substance means a diminution of the role of individual substances in favour of the second or universal substances.

Important for the transition to Leibniz's metaphysics is Spinoza's thesis that a substance only can be a substance if it contains all the attributes. This foreshadows Leibniz's conception of individual substances containing all properties, and his thesis that all these accidents or properties have to be present, i.e. Leibniz's hyperessentialism. 


\section{Leibniz on substance}

The young Leibniz studied the Aristotelian theory of substance with Erhard Weigel. But it was already before his studies in Leipzig and Jena that he read the books of the scholastic philosophers of the sixteenth century. Especially the ontology of Francisco Suàrez had great influence on him. Suàrez held a strict ontological individualism with individual substances and individual accidents inhering in these substances.

The first work in which Leibniz formulated his own theory of substance was the Discours de Métaphysique of 1686. In this work Leibniz starts his exposition with God and he continues it with living substances like human beings and animals, and finally he comes to bodies and matter. Some analyses and theories of Leibniz concerning substance are quite new and even revolutionary. He evidently is interested in the rehabilitation of individual substances together with their substantial forms. In contradistinction to his predecessors, for Leibniz God is not a substance, but a perfect entity (entité parfaite) with characteristic perfections such as omnipotence, omniscience and maximal goodness. ${ }^{9}$ All living entities are substances, and Leibniz thinks that every individual substance corresponds to an individual concept, or a conceptus completus. ${ }^{10}$ All the properties of an individual substance fall under subordinate concepts of its corresponding individual concept. These properties comprehend all activities and passivities of the substance, i.e. all that it does and all that comes from the outside or what happens to it. The person, who possesses this individual concept, is able to reconstruct the whole substance, because the individual concept contains past, present and future of the corresponding substance. Individual concepts can be seen as maximally-consistent concepts, since they contain all the mutual consistent subordinate concepts. Note that Leibniz rejects Aristotle's characterization of substance as the endpoint of predication and inherence as a nominal definition. ${ }^{11}$

This conception of substance leads to another Leibnizian thesis about a fundamental ontological problem: the problem of individuation. This problem had already been the subject of his doctoral thesis in Leipzig from

\footnotetext{
${ }^{9}$ Cf. Discours, $§ \S 1-7$.

${ }^{10}$ In his correspondence with Arnauld, Leibniz distinguishes between conceptus completus or complete concept and conceptus plenus or full concept. GP II 52, Cf. Burkhardt 1980, 166ff.

${ }^{11}$ Cf. Discours, $\$ 8$.
} 
1662 that had the title: Dissertatio metaphysica de principuo individui. In this dissertation Leibniz rejected all four traditional theories of individuation (matter, form, haecceity and number), and he already was sympathetic with the entitas tota. Later he held a hyperessentialism, i.e. every property of the substance is important and essential, no property should be absent, for if one property were absent, then the individual could be part of another possible world. Leibniz takes from the Scholastics of the sixteenth century the concept of possible worlds, and it becomes a terminus technicus in his philosophy.

When Leibniz in the Discours speaks about perceptions and substances, he goes beyond the Aristotelian-scholastic conception of substance. Due to its perceptions, every substance mirrors the whole world, and each substance does it in a different way, i.e. more or less clearly and distinctly. The qualitative degree of this mirroring determines the place of the corresponding substance within the hierarchy of substances.

Besides these perceptions, which are irreflexive, symmetric and transitive qua relations, there are also reflexive psychic acts, which Leibniz calls apperceptions. We find these reflexive psychic acts only in the mind of rational substances. By their reflexivity apperceptions constitute consciousness, and because these rational substances or souls have access to the world of ideas, they form a special kind of memory, i.e. a memory for necessary or even eternal truths or truths that cannot be otherwise. These truths are typical for certain sciences, such as mathematics, logic and metaphysics. They have to do with different kinds of laws and norms, with alethic, ontological and deontic norms. In this case we can speak of an ego, which has the capacity to unify the apperceptions and the other psychic acts that are part of human consciousness, and by this means the ego also guarantees the unity of the consciousness. This ego is the presupposition for an individual to become a person and therefore to be responsible for his actions. Besides individual substances Leibniz also accepts persons who are dependent on apperceptions and therefore are also defined via apperceptions. $^{12}$

The Discours is a work of transition. On the one hand we find parts or themes of traditional substance ontology and philosophical grammar, for example substance, subject, accidents, quality, predicates, substantial forms, infima species, and examples such as "Caesar crossed the Rubicon," or "Caesar won the battle of Pharsalus." On the other hand we find his

${ }^{12}$ Cf. Discours, $§ 12$. 
conception of abstract perceptions that mirror the whole universe, a conception that already foreshadows the abstract metaphysics of the Monadology. Thus we see that the Discours expresses perfectly Leibniz's Janusheaded attitude. One face looks back in the past, i.e. toward philosophical tradition and the other to the future, and in this case to Leibniz's own philosophical future, and by this also to the future of Western philosophy in general.

In his Monadology of 1714 we find quite a new approach to the problem of substance. Leibniz begins this work with simple substances (substantia simplex), which he calls monads. In the first three paragraphs he declares that these monads do not have any parts, and he means substantial parts. Simple substances or monads are able to form connections with other monads. Leibniz calls these connections aggregates. From the correspondence with Bartholomaeus des Bosses we learn that there are two main kinds of connections between simple substances or monads. On the one hand, there are true aggregates, i.e. connections of monads in which each part or each monad is able to exist without the other parts. ${ }^{13}$ These connections are not true wholes, since their unity is not internal, but external. Thus their unity has something accidental, because it can be caused either by sense perceptions or by apperceptions qua thinking by concepts or by a combination of the two. Therefore, Leibniz calls these aggregates substantita and characterizes their unity as una per accidens. There is a hierarchy of aggregates that depends on the intensity of the relations between their parts. Leibniz is the author of a rich philosophy of aggregates of different kinds.

On the other hand, there is another kind and result of connection, the composed substance (substantia composita), that is characteristic of living entities. In this case a set of monads is dominated by one monad. This monad consequently and rightly can be called the dominating or central monad (Leitmonade). The dominating monad is identical with the soul of a living entity. Leibniz calls it entelechia prima of the composed substance. Like simple substances, composed substances have an internal unity. Due to their dominating monads they are una per se. In the quoted text Leibniz consequently calls them not substances but substantiata, in contrast to pure aggregates, or substantiata una per accidens, substantiata una per se.

${ }^{13}$ GP II 459, Footnote: Porro substantialia divido in substantias simplices, ut Deus, Angelus, anima, et substantiata: substantiatum in unum per se seu substantiam compositam, et unum per accidens seu aggregatum. 
From this it follows that living substances are not individual substances tout court as it is the case in the ontology of Aristotle and the Scholastics, but they are composed of an infinity of monads coordinated and dominated by their central monad. Due to the relation of domination there is both a supreme and a lowest barrier, i.e. rational monads are not dominated and simple monads do not dominate. ${ }^{14}$

Simple substances are partless, but they have certain determinations or qualities that are called perceptions and appetitus by Leibniz. ${ }^{15}$ These perceptions are responsible for the fact that every simple substance or monad reflects all the other monads in the universe, and the appetite organizes the transition from one perception to the next perception, or at least to a part of it. $^{16}$ The action of the internal principle which brings about the change or the passage from one perception to another may be called appetition. ${ }^{17}$ Therefore, the appetite is the dynamic principle of the monad. Because of these determinations or qualities, and due to the appetite, there is movement in the monads and consequently change. As already explained, higher or rational monads possess reflexive psychic acts or apperceptions and therefore also consciousness. Similar to the composed substances perceptions and appetites present a mereological structure. Leibniz thinks that they are composed of an infinite number of petites perceptions and petites inclinations. $^{18}$

Monads mirror each other, but despite this mirroring they do not influence each other, i.e. in contrast to Aristotle's individual substances, there is no causal influence, conceived as causa efficiens among the monads. Instead of causal relations there exists a special kind of parallelism that is rooted in Leibniz's (or better God's) preestablished harmony. This harmony holds, for example, between body and soul. This is Leibniz's solution to the problem of causality, which the Rationalists inherited from the

${ }^{14}$ Cf. Schneider 2001, 40-42, where we find the best analysis and presentation of the relation of domination. Cf. Schneider 2006, 134-35.

${ }^{15}$ Monadology $\$ 8$, cf. GP II 270: Imo rem accurate considerando dicendum est nihil in rebus esse nisi substantias simplices et in his perceptionem et appetitus.

${ }^{16}$ Cf. Monadology, \$15.

${ }^{17}$ Cf. Rescher 1991, 18.

${ }^{18}$ GP III 657: Car nos grandes perceptions et nos appetits, dont nous nous apercevons, sont composés d'une infinité des petites perceptions et petites inclinations, dont on ne sauroit s'apercevoir. (Letter to Remond from November 4, 1715); cf. Burkhardt and Degen 2005, 160-62. 
scholastic philosophers of the sixteenth century, especially the Jesuits. ${ }^{19}$ In the realm of phenomena, which is our world, there are causal relations, but not in the world of monads, which together with the world of ideas in God's mind are the fundament of the phenomena bene fundata. Although it is often stated in some translations and publications, in the realm of monads perceptions are not sense perceptions as they really are in the realm of phenomena, but are to be conceived as a very abstract mirroring of all other monads. After all, how could a monad reflect all the other monads together with their perceptions by its senses?

In his correspondence with Arnauld, Leibniz was looking for an entity that he called corporeal substance. But in 1690 he gave up this idea, and ended up with his theory of spiritual substances or monads. This was a new way, and he has not found many successors. Whitehead may be an exception. As a consequence of this move, his conception of matter is fundamentally different from that of the other important Rationalists. Consequently matter also has a different ontological status. Far from being a res extensa or even a substance, matter is a phenomenon bene fundatum, i.e. a well founded phenomenon. The ontological fundament of the purely phenomenal character of matter is either the pure aggregates or, in the case of living substances, the dominated monads, i.e. all the monads that are passive in the sense that they are dominated by a central monad or soul. These monads also present a hierarchic structure, dependent on the quality of their mirroring of the other monads, i.e. on how clear and distinct this mirroring is. Matter and body have only a weak ontological status in Leibniz's metaphysics. This is radically new in the history of philosophy, and not without philosophical consequences.

Concerning his conception of substance, Leibniz distances himself from Descartes and Spinoza, and although some of his theses surely are reactions to their conceptions, he seems to be much more influenced by the foregoing Aristotelian-scholastic tradition. The Leibnizian approach to the concept of substance is characterized by the following items.

4.1 There is no place for attributes.

4.2 We find a renaissance of the individual substance.

4.3 We find also a renaissance of the substantial forms.

\footnotetext{
${ }^{19}$ In the sixteenth and seventeenth centuries the philosophers discussed three kinds of causality: (1) Creation, (2) Conservation (creatio continua), and (3) Concursus Dei. Cf. Ramelow 1997, passim.
} 
4.4 Leibniz introduces the individual concept.

4.5 In 1690 he gives up his search for corporeal substances.

4.6 In 1690 he introduces a spiritual substance that he calls monad.

4.7 In the monads we find perceptions and appetites.

4.8 Matter and bodies are phaenomena bene fundata.

4.9 Simple substances or monads are able to build up aggregates of different kinds.

Some of these conceptions have already been discussed in the foregoing passages of the paper, but some short remarks on the different points will make Leibniz's theory of substances clearer.

4.I Leibniz had great problems with the Cartesian attribute of extension, because he thought that extension is not at all characteristic for matter. ${ }^{20} \mathrm{As}$ a physicist and philosopher, Leibniz thinks that force is more fundamental for matter than extension, and he introduces the concept of force into physics. Thus he rejects res extensa. On the other hand in contrast to Descartes he thinks that also animals have perceptions and memory. That means on the one hand that perceptions without thinking are possible, and on the other hand that animals, having perceptions, are not simply machines, and therefore Leibniz rejects also res cogitans.

4.II In the Discours de Métaphysique Leibniz holds the theory of individual substances, and he speaks of accidents inhering in these substances. His examples are traditional ones.

4.III Together with the individual substance, Leibniz in the Discours also introduces substantial forms, in which the individual substance is imbedded.

4.IV The introduction of the individual concept in metaphysics is revolutionary. It can be seen as a maximally-consistent concept, and with this concept Leibniz paves the way for later developments of his metaphysics.

4. $\mathrm{V}$ In his correspondence with Arnauld, Leibniz is convinced that there must exist an entity that could be called corporeal substance.

4.VI Finally, in 1690, Leibniz gives up his search for a corporeal substance, and he introduces a purely spiritual substance that he calls monad.

${ }^{20}$ Cf. Discours, $\S 13$. Extension (size), figure and motion cannot constitute a substance, because they are too dependent on sense perception. This argument foreshadows Leibniz's later theory of aggregates and phenomena bene fundata. 
4.VII In monads we find nothing else than perceptions and appetites which show a mereological structure qua petites perceptions and petites inclinations.

4.VIII After giving up the concept of corporeal substance, Leibniz conceives matter as a phenomenon bene fundatum.

4.IX Leibniz distinguishes between two kinds of aggregates which he calls substantiata per accidens and substantiata per se. Substantiata per accidens are true aggregates, because each part is independent of the whole and can exist without the whole. Their unity is external and not internal. All living substances are substantiata per se. In this case the unity is internal, and the elements cannot exist without the corresponding whole. There are also aggregates composed not of monads but of whole living entities. Leibniz mentions as examples a flock of sheep or an army.

\section{Final remarks}

Whereas during the whole Aristotelian-scholastic tradition, including the sixteenth century, the theory of substance was one of the constants in ontology, metaphysics and theology, and substance was as such a reliable entity, the concept of substance in the seventeenth century became blurred and consequently also its ontological status and importance. This is valid for all forms of substances, for individual substances, universal or second substances, substantial forms, spiritual and corporeal substances. The philosophers of the seventeenth century had to look for compensation and substitutes, and with remarkable imagination and industry they found it in form of res extensa and res cogitans, attributes, individual concepts, substantiata una per se et per accidens or aggregates, monads, perceptions and appetitions. As a consequence also the ontological status of properties, attributes, modes and accidents became unclear and questionable, due to their connections with substance by relations such as inherence, predication, instantiation and exemplification.

Descartes, an excellent mathematician and a physicist, saw clearly and distinctly that the concept of substance has no future in physics and mechanics, the new and dominating sciences, and he replaces corporeal substances by res extensa, i.e. by an extended thing. In contrast to the res extensa the res cogitans is instantiated. There are thinking individuals or individual human beings, who by introspection know that they exist and that they have an ego. Thus they are able to become persons responsible for their actions. 
Spinoza was not much influenced by scientific reflections, but he was impressed and influenced by the axiomatic-deductive structure of geometry, and as many other scientists and philosophers of this time, he applied this structure to philosophy in his main work the Ethica. His concept of substance fits very well in this methodological frame, because there is only one substance identical with God, and all the other entities are within this substance, and therefore can be deduced from it.

Leibniz, also a creative mathematician and physicist, goes in quite another direction. He wanted to construct a metaphysical system which would encompass all kinds of scientific knowledge of his time or epoch. ${ }^{21}$ This system had to be very abstract and far from sense perception, imagination or Anschauung. Nicholas Rescher, an excellent Leibniz scholar and a Kantian, has expressed these connexions and facts perfectly:

Leibniz was the first metaphysician of the Western tradition who sought to construct reality out of units possessing a property structure wholly beyond the reach of our everyday experiences. Anticipating twentieth-century physics in this respect, Leibniz dared for the first time to envision a reality that emerged from the operation of a reality that lies totally beyond the reach of human observation. His theory of substance is a leap into an order of reality which, for the sake of being intelligible, leaves the sensible domain almost totally behind, a position which the more conservative Kant was to regard as a decisive defect. $^{22}$

While Descartes is a dualist, accepting two very weak forms of substances which he calls res or things, Spinoza and Leibniz are monists. Spinoza is a monist concerning the kind and number of substances; he thinks that there is only one substance identical with God. Leibniz is a monist concerning the kind of substances: he accepts only spiritual substances or monads and rejects corporeal substances.

What are the consequences for a philosopher of the twenty-first century who sympathizes with substance ontology? Is he condemned to work exclusively as a historian of philosophy in order to become an appreciated member of German philosophical society? I don't think so, because in my opinion, the ontology of states of affairs is compatible with substance ontology, and the ontology of occurrents and continuants is nothing else than

${ }^{21}$ Cf. Rescher 1991, 13.

${ }^{22}$ Cf. Rescher 1991, 12. 
a variant of it. ${ }^{23}$ Thus, as long as trope ontology, process ontology or cluster or bundle ontology are its true and most dangerous current rivals, substance ontology has a very good chance of surviving.

\section{REFERENCES}

Angelelli, I. 1967 Studies on Gottlob Frege and Traditional Philosophy, Dordrecht: Reidel.

- 2006 "The interpretations of "nihil nullae sunt proprietatis. A Text from Rubi.", in G. Imaguire and C. Schneider (Hrsg.), Untersuchungen zur Ontologie, München: Philosophia, 41-53.

Burkhardt, H. 1980 Logik und Semiotik in der Philosophie von Leibniz, München: Philosophia.

- 1989 "The Part-Whole Relation in the Metaphysics of Leibniz", in N. Rescher (ed.),

Leibnizian Inquiries. A Group of Essays, Lanham/New York/London: University of America Press, 171-81.

- and Degen, W. 1990 "Mereology in Leibniz's Logic and Philosophy", Topoi, 9, No $1,1-13$.

- 1990 “Adam's Mind and Body", in M. Dascal, and E. Yakira (eds.), Leibniz and Adam, Tel Aviv: University Publishing Projects Ltd., 39-56

- 1995 „Leibniz als Mereologe“, in Leibniz und Europa, VI. Int. Leibnizkongress, Vor-

träge II., Hannover, 47-56.

- 1999 „Aggregate“, in D. Berlioz and F. Nef (eds.), L'actualité de Leibniz: Les deux

Labyrinthes, Studia Leibnitiana Supplementa 34, Stuttgart: Franz Steiner Verlag, 307-319.

- and Degen 2003 “W. Leibniz's Metaphysics: New Concepts via old Terms. Parts of

Perceptions and Appetites», in D. Berlioz and F. Nef (eds.), Leibniz et les Puissances du Langage, Paris: J. Vrin, 151-162.

- 2006 „Dekonstruktion und Rekonstruktion des Substanzbegriffes im 17. Jahrhundert.

Descartes, Spinoza, Leibniz“, in H. Breger, J. Herbst, and S. Erdner (eds.), Einheit und Vielheit. Vorträge I. Teil, 118-22.

Correia, F. 2005 Existential Dependence and Cognate Notions, Munich: Philosophia.

Descartes, R. 1967 Discours de la Méthode. Texte et Commentaire par Étienne Gilson, Paris: Vrin.

- 1897-1910 Oeuvres. Vol. I-XII, ed. Ch. Adam/ P.Tannery. Paris = AT.

Gilson, É. 1912 Index Scolastico-Cartésien, Paris, Reprint New York: Burt Franklin. Kenny, A. 1968 Descartes, New York: Random House.

Leibniz, G.W. 1965 Die philosophischen Schriften. Herausgegeben von C.I. Gerhardt, VII Bde, Berlin 1875-1890. Nachdruck Hildesheim 1965 (=GP).

${ }^{23}$ Already scholastic philosophers, for example Walter Burleigh, distinguished between ens permanens (continuant) and ens successivum (occurrent). 
- 1991 Monadology. An Edition for Students, by N. Rescher, Pittsburgh: University of Pittsburgh Press.

Petrus, Hispanus Portugalensis 1972 Tractatus/Summule Logicales. First Critical Edition from the Manuscripts with an Introduction by L.M. De Rijk, Assen: Van Gorcum \& Comp.

Ramelow, T. 1997 Gott, Freiheit, Weltenwahl, Leiden, New York, Köln: E.J. Brill.

Schneider, C. 2001 Leibniz' Metaphysik. Ein formaler Zugang, München: Philosophia.

- 2006 „Leibniz' ideelle, phänomenale und monadische Welt. Zur Tragfähigkeit seines metaphysischen Koordinatensystems", in H. Breger, J. Herbst, and S. Erdner (eds.), Einheit und Vielheit. Vorträge II. Teil, Hannover, 931-36.

Spinoza, B. 1924 Opera, 4 volumes, Heidelberg: Carl Winters Universitätsbuchhandlung.

Trettin, K. 2006 "How Things are connected. On Leibnizian Relations, Inherence, and Dependence", ibid., 1074-1080.

Woolhouse, R.S. 1995 Descartes, Spinoza, Leibniz. The Concept of Substance in Seventeenth Century Metaphysics, London and New York: Routledge. 
